\title{
A ESCRITA E A HUMANIZAÇÃO DO SUJEITO NEGRO: AFROCENTRICIDADE EM LA DIOSA Y LA NOCHE: LA NOVELA DE ROSA LUNA, DE JORGE CHAGAS
}

\author{
A ESCRITA E A HUMANIZAÇÃO DO SUJEITO NEGRO: \\ AFROCENTRICIDADE EM LA DIOSA Y LA NOCHE: LA \\ NOVELA DE ROSA LUNA, DE JORGE CHAGAS
}

\author{
Diego Bonatti \\ [https://orcid.org/0000-0002-8775-6112] \\ DOI: $10.30612 /$ raido.v15i37.13642
}

RESUMO: Neste trabalho, investigamos a obra La diosa y la noche: la novela de Rosa Luna, do escritor afro-uruguaio Jorge Chagas enquanto expressăo de uma narrativa afro-centrada e afro-realista. Rosa Luna foi uma das maiores dançarinas de Candombe no Uruguai. Sua fama perpassa a infância pobre no Conventillo Mediomundo - espaço histórico afro-uruguaio, até a fama internacional. Na narrativa, identificamos a valorizaçâo da cultura negra, o que, em aspectos teóricos, pode ser associada à expressăo do paradigma afrocêntrico por meio da literatura, isto é, de descoberta/ valorizaçăo da identidade negra e resgate das raízes ancestrais, conforme Nascimento (2009). Para Mazama (2009), posicionar-se de modo afrocêntrico, isto é, tendo a África como referência, é enfrentar a supremacia branca e suas formas de violência. Por outro lado, o destaque às culturas negras da diáspora na literatura latino-americana, para Duncan (2005), acaba por criar um novo movimento estético-literário, o Afrorealismo, que além da temática, significa a expressăo de uma voz negra no campo literário, assim como o reencontro com a ancestralidade e memória negra. Assim, Chagas, ao representar as vivências de Rosa Luna, realiza o resgate da presença negra no Uruguai, representando-a sem estereótipos e a partir de uma literatura afrocentrada e humanista.

Palavras-chave: Literatura uruguaia; La diosa y la noche; Afrocentricidade; Jorge Chagas.

ABSTRACT: En este trabajo investigamos la obra La diosa y la noche: La Luna de Rosa Luna, del escritor afro-uruguayo Jorge Chagas como expresión de una narrativa afrocéntrica y afro-realista. Rosa Luna fue una de las más grandes bailarinas de Candombe de Uruguay. Su fama pasa por su pobre infancia en el Conventillo Mediomundo - espacio histórico afro-uruguayo, hasta la fama internacional. En la narrativa, identificamos la valorización de la cultura negra, que, en aspectos teóricos, se puede asociar con la expresión del paradigma afrocéntrico a través de la literatura,

1 Graduado em Letras - Inglês pela Universidade Regional Integrada do Alto Uruguai e das Missōes - URI Campus Frederico Westphalen - RS. Mestre em Literatura pela UFRGS. E-mail: diego.bonatti@bol.com.br 
es decir, el descubrimiento / valorización de la identidad negra y el rescate de raíces ancestrales, según Nascimento (2009). Para Mazama (2009), posicionarse de manera afrocéntrica, es decir, con África como referente, es enfrentar la supremacía blanca y sus formas de violencia. Por otro lado, el énfasis en las culturas negras de la diáspora en la literatura latinoamericana, para Duncan (2005), crea un nuevo movimiento estético-literario, el Afrorealismo, que además de la temática, significa la expresión de una voz negra en el campo literario, así como el reencuentro con la ascendencia y la memoria negra. Así, Chagas, al representar las vivencias de Rosa Luna, rescata la presencia negra en Uruguay, representándola sin estereotipos y desde una literatura afrocéntrica y humanista.

Keywords: Literatura uruguaya; La diosa y la noche; Afrocentricidad; Jorge Chagas.

\section{INTRODUÇÃO}

É estranho que um país conhecido pelo carnaval năo reclame a si mesmo a identidade negra. Apesar do frequente "esquecimento" de suas raízes, o Uruguai é, sim, um território negro, com a presença de cidadâos e cidadās negras que têm suas histórias no País ligadas a movimentos histórico-sociais de escravidāo, migraçâo e diáspora. Dados do censo de 2011 revelam que cerca de 10\% dos uruguaios têm descendência negra, e que a maior parte dessa populaçăo reside na fronteira com o Brasil:

De acuerdo al Censo 2011, en torno al 90\% de la población uruguaya considera que tiene ascendencia blanca y que esta es su ascendencia principal. Los afrodescendientes son, desde el punto de vista cuantitativo, la principal minoría étnico-racial del país; $8,1 \%$ de la población total con información relevada declara ascendencia afro y 4,8\% la considera su ascendencia principal. La distribución en el territorio es muy heterogénea: en la mayor parte del país la población afrodescendiente no supera el $5 \%$ de la población, en tanto que en algunas zonas llega a ser casi un tercio del total departamental. Los departamentos con la mayor proporción de afrodescendientes se ubican al norte del país, en la frontera con Brasil: Rivera (17,3\%) y Artigas (17,1\%). (CABELLA [et al.] 2011, p. 70).

A constituiçăo de um grupo minoritário numericamente, entretanto, nâo justifica a posiçăo marginalizada e quase esquecida que os afrodescendentes ocupam no Uruguai. Apesar de movimentos históricos que impuseram o silenciamento e o "embranquecimento" da cultura nacional, é possível observar, na contemporaneidade, movimentos sociais e artísticos que visam à ruptura com a herança eurocêntrica racista.

No campo das artes, mais especificamente da literatura, observa-se a crescente produçâo de narrativas que reescrevem e questionam a colonizaçấo, principalmente nos países onde houve o uso de măo de obra escrava. A redescoberta e reafirmaçăo da presença negra faz com que obras como La diosa y la noche: La novela de Rosa Luna (2017), do escritor uruguaio Jorge Chagas, sejam publicadas. Nessa narrativa, é contada a história de Rosa Luna, mulher negra e famosa vedete do carnaval uruguaio, que apresenta uma trajetória de vida marcada pelo engajamento e promoçâo da cultura negra, assim como o empoderamento das mulheres no País. Assim, por meio da escrita de Jorge Chagas, identificamos a evidenciaçăo de características como o orgulho e a busca das raízes africanas, da mesma forma que a valorizaçăo da identidade negra. 
À medida que cada vez mais pensadores e artistas se aliam à ideia de uma redescoberta da África, ou da herança negra presente em cada sujeito negro em situaçâo de diáspora, manifestaçâo cultural, saberes e narrativas, reinventa-se a História, reescrevendo-a a partir de versōes e eventos até entăo desconsiderados ou desconhecidos. A pluralidade e riqueza de movimentos que buscam, muito mais do que falar sobre África, ouvir o que os povos e culturas pretos têm a nos ensinar, ganha força, se expande, e acaba por constituir um paradigma de conhecimento, nomeado Afrocentrismo. Na perspectiva de Mazama (2009), o afrocentrismo constitui uma forma de respeito à cultura, história e ancestralidade negras. Na mesma linha de pensamento, Finch \& Nascimento (2009) destacam que a afrocentricidade representa, também, uma forma de resistência à dominaçâo e depreciaçăo do sujeito negro imposta pelo eurocentrismo. Já o pesquisador costarricense Quince Duncan (2005), ao investigar a literatura negra latino-americana, propôe a criaçăo de um novo movimento estético-literário, o Afro-realismo. Para Duncan, esse movimento propóe uma descentralizaçăo temática, à medida que busca o reencontro com o passado africano e a valorizaçăo da ancestralidade africana por meio do uso de uma voz negra na literatura.

Desse modo, a partir de uma escrita apoiada no paradigma afrocêntrico, Jorge Chagas devolverá, em La diosa y la noche, uma narrativa que, à medida que reencena fatos de uma das mais conhecidas mulheres afro-uruguaias, devolve a humanizaçâo do sujeito negro, da qual foi extirpado pelo processo de colonizaçăo. Frantz Fanon, em Os condenados da Terra (1968), descreve a desumanizaçáo do negro como um dos pontos fundamentais empregados pelo processo colonizatório. Nesse processo, a criaçăo de estereótipos, a destituiçấo da posse de razầo, a anulaçăo dos saberes e a classificaçáo da cultura como primitiva pelos europeus em relaçăo aos povos africanos constituiu o processo de separaçăo do negro da categoria "humano", colocando-o numa posiçăo subalterna, de inferior e, portanto, passível de dominaçăo.

Nessa perspectiva, busca-se, neste artigo, a partir de uma contextualizaçăo histórica, analisar a obra La diosa y la noche enquanto expressáo de um posicionamento afrocentrado do escritor Jorge Chagas que, à medida que narra a vida de Rosa Luna, reescreve a história do Uruguai, ressignificando o passado de desumanizaçăo, subalternidade e exploraçăo a que os sujeitos negros foram submetidos e colocando-os numa posiçấo de destaque, respeito e consciência histórica.

\section{ENEGRECENDO 0 URUGUAI}

Partindo de uma perspectiva geográfica, a distância que separa um pequeno país da Bacia do Prata, da África, parece enorme. Apesar de $7000 \mathrm{~km}$ separarem fisicamente os dois territórios, é possível analisar uma relaçăo de longa data entre os dois espaços. O oceano Atlântico, que poderia se tornar uma barreira entre as Américas e a Africa, converteu-se em uma fronteira líquida que, ao separá-los, os aproxima.

Gonzálo Abella, em Historia diferente Del Uruguay (2007), inicia a narraçăo dos fatos históricos do país com a perseguiçâo e extermínio da populaçāo indígena pelos colonizadores. Os Charrúa, grupo étnico dominante do atual território do Uruguai, do qual faziam parte os Guenoas, o Bohanes e os Minuanos, que habitavam "[...] Las praderas [...] conserranías, grandes ríos, lagunas navegables y frontera oceánica." (ABELLA, 
2007, p. 29). A vida desses povos originários, entretanto, começa a se modificar em 1492, com a chegada dos colonizadores europeus, que passam a dominá-los a fim de transformá-los em escravizados para as plantaçôes de cana-de-açúcar. O conflito entre indígenas e povos invasores se intensifica ainda mais por volta de 1700, quando os bandeirantes passam a matá-los e persegui-los, fazendo com que os sobreviventes fugissem para as montanhas e lá se isolassem.

Já a presença negra no Uruguai pode ser associada à chacina dos povos indígenas causada pela transmissāo de doenças trazidas pelos colonizadores, assim como à exposiçâo a condiçóes de vida precárias e extrema exploraçăo na condiçăo de mâo de obra, que passa a ser substituída por africanos escravizados. Abella (2007) registra a presença dos bandeirantes no território platino desde 1631, e que esses, além de expandirem o território brasileiro por meio de expediçóes, capturavam indígenas e realizavam o comércio de escravizados africanos.

Conforme Bracco [et al.] (2012), em Esclavitud y afrodescendientes em Uruguay, Montevidéu servia como porto de entrada dos escravizados trazidos, muitas vezes, por meio do transporte ilegal para a colônia, isto é, "sem a autorizaçăo do rei". A origem dos escravizados trazidos para a colônia uruguaia era variada, vindos de lugares como "[...] las costas de Guinea, Congo, Angola, Mozambique (en África) y otros desde Brasil." (BRACCO, 2012, p. 14). Esses escravizados eram capturados e, quando chegavam às Américas, eram violentamente expostos a uma nova cultura, a europeia, novas línguas - as dos colonizadores, e novas crenças - eram batizados na religiâo Católica, e a eles era imposta uma nova identidade já que recebiam um novo nome aos moldes de uma cultura branca e europeizada.

A quantidade de escravizados no Uruguai enquanto colônia é um número difícil de ser calculado com exatidāo devido a fatores como a perda de registros oficiais e pela ausência de documentos das açôes do tráfico negreiro:

En muchos países, por diferentes factores, la documentación relacionada a la trata no se ha conservado. En Uruguay, los registros de las embarcaciones negreras se quemaron en un incendio que se produjo en las instalaciones de la Aduana, en el siglo XIX. Por otra parte un número muy importante de esclavos llegan a las colonias de contrabando. Evadiendo las restricciones de comercio y/o los impuestos no dejan registros. Hoy se admite que la cifra estaría cerca a los 12.000 .000 de personas. Pero la cantidad de africanos que fueron afectados por este flagelo, entre el siglo XVI y el siglo XIX, fue mucho mayor. Se estima que durante la captura pueden haber muerto entre 1 a 2 millones. Una cifra similar o mayor alcanzó la mortalidad por las condiciones inhumanas a las cuales eran sometidos durante el viaje. (BRACCO, 2012, p. 11).

De acordo com Borucki (2011) citado por Bracco [et al.] (2012), entre 1786 e 1821, pelo menos 60.000 escravizados oriundos da África ou do Brasil chegaram ao Uruguai, sendo que, dos registros disponíveis, entre os trabalhadores domésticos, a maioria era serventes (315), lavadeiras (721), cozinheiros (455) e amas de leite (56). Além das atividades agrícolas com plantaçôes, criaçáo de animais e produçâo de charque, os escravizados também participaram de importantes eventos históricos como a Guerra do Paraguai e a Guerra Grande - Guerra Civil Uruguaia, com a promessa de receberem alforria após a vitória. (SAINT-HILAIRE, 1827, Voyage a Rio Grande do Sul, apud BRACCO [et al.], 2012). 
Apesar da presença histórica negra, a amnésia parece ter dominado a História Oficial, que muitas vezes vê o País platino como branco europeizado, apenas. Diante disso, Bracco [et al.] (2012) denunciam a presença negra em terras platinas quando, em 1608, chega no atual território uruguaio uma expediçấo com trinta escravizados(as). Depois,

En el ańo de 1680 los portugueses fundan Colonia del Sacramento, convirtiéndose en un importante centro de introducción. Se introducían a través de esta nueva puerta del Río de la Plata unos 1.200 esclavos al ańo. La mitad tuvieron como destino Buenos Aires, mientras el resto fueron distribuidos por la región. (BRACCO [et al.], 2012, p. 15).

Segundo Bracco [et al.] (2012), a Real Compañía de Filipinas era a organizaçăo responsável por realizar o comércio dos escravizados nos portos de Montevidéu, Chile e Perú, trazendo a primeira leva de escravizados no ano de 1788. Para abrigar os escravizados que chegavam, e a fim de deixá-los em quarentena para possíveis doenças, é construído, também, o Caserío Filipinas, ou mais popularmente conhecido como Caserío de Los Negros, uma espécie de "senzala temporária" que servia de entreposto. Esse espaço ficava para além dos muros da cidade, localizando-se, portanto, na margem, espaço destinado desde sempre pelo poder colonial a todos e tudo aquilo que náo faz parte da Metrópole. A simbologia dessa construçăo significa o início da construçăo e urbanizaçăo do Barrio Capurro em Montevidéu.

A partir do século XIX, ideais abolicionistas começam a se espalhar pelo mundo com o fim do tráfico negreiro por parte da Inglaterra. Tais perspectivas têm influência direta na aboliçâo, pelo menos na forma da Lei, da escravatura no Uruguai, de modo que, em 1813 é declarada a Libertad de Vientres, isto é, a lei que garantia a liberdade de filhos de ex-escravizados, assim como declarava que "[...] los esclavos de países extranjeros serán libres 'por el solo hecho de pisar el territorio de las Provincias Unidas'." (BRACCO [et al.], 2012, p. 28). Também, em 1825, sâo declarados livres todos os escravizados independente de suas origens, estrangeiros ou năo, e em 1830, a Constituiçăo da República, no art.131, determina que “En el territorio del estado nadie nacerá ya esclavo; queda prohibido para siempre su tráfico e introducción en la República." (BRACCO [et al.], 2012, p. 28). Por fim, em 1837, é criada novamente outra Lei que determina o fim do tráfico escravista e a liberdade de todos os escravizados ou sujeitos negros que entrassem em território uruguaio, porém colocava sob tutela os menores de idade até os 25 anos e os maiores dessa idade até completarem três anos de serviço no exército.

Nas forças armadas, os escravizados participaram, por exemplo, da Guerra Grande - Guerra Civil, os homens como combatentes e as mulheres e crianças no trabalho e produçăo de artigos para venda, dinheiro este que era roubado pelos senhores aos quais a populaçấo negra estava sob tutela. Com o fim da Guerra em 1851, acontece a emancipaçâo dos soldados, isto é, o fim do período de tutela dos que lutaram e de seus familiares. O fim "oficial" da escravatura é declarado somente em 12 de dezembro de 1862, pelo Governo de Defesa.

O cumprimento dessas leis, como se sabe, foi parcial, e o trabalho deixou de ser "escravo" para tornar-se apenas "minimamente remunerado". Os ex-escravizados, agora "livres" e assalariados, tinham, na verdade, que se submeter a situaçôes precárias de vida e, muitas vezes, continuar a servir seus ex-senhores por falta de outras 
oportunidades. A populaçăo negra e indígena, a fim de inserir-se na sociedade uruguaia deveria, entâo, "embranquecer" para ser aceita:

El afrodescendiente, junto al indio asimilado y al inmigrante pobre, pasó a ser parte del proletariado urbano y rural menos calificado. Se establecieron normas que reglamentaron su trabajo, su diversión, su vida. Los centros educativos (como la escuela), eran los lugares desde los que se enseñaban las reglas para poder ser integrados por la nueva sociedad: hábitos de higiene, de trabajo, de ahorro, de familia. (BRACCO [et al.], 2012, p. 32).

O sequestro da presença negra no País platino, entretanto, deixou marcas profundas na cultura local e que năo podem ser apagadas nem esquecidas. Além do trabalho nas fazendas, e o trabalho braçal ou doméstico nas cidades, a populaçăo negra uruguaia tem sua presença frequentemente associada a duas paixóes nacionais: o futebol e o carnaval. Nesta perspectiva, ressaltamos o ritmo Candombe como registro cultural em que a presença feminina tem maior destaque.

Enquanto importante personagem da história colonial das Américas, a mulher negra, segundo Abella (2007), além de trabalhar para os senhores, criando, limpando e dividindo o leite de seus próprios filhos com os do patrăo, desempenhava, sobretudo, a funçâo simbólica de gestaçâo, cuidado e transmissāo da memória e cultura africanas. Segundo o autor,

Las mujeres afroamericanas, en medio de las terribles condiciones de su existencia, tuvieron más posibilidades que sus compañeros varones de transferir a los hijos las memorias culturales de la resistencia. Ellas fueron los canales de la memoria, ellas urdieron los hilos secretos de las redes solidarias entre los negros prófugos y los que vivían en aparente sumisión. Ellas aportaron al mundo gaucho las creencias y las prácticas rituales, artesanales y agropoductivas de su (nuestra) Madre Patria africana. Quien dice prácticas rituales dice también ritmos y melodías. (ABELLA, 2007, p. 65, grifos nossos).

O candombe é gestado, transmitido e ganha força pela açăo das mulheres: elas transmitiram a memória musical e, pelo corpo, pelo gingado, o fizeram ganhar ritmo. Assim, o Candombe é um ritmo genuinamente uruguaio, tendo seu reconhecimento como Patrimônio Cultural Imaterial da Humanidade pela UNESCO em 2009:

El candombe es un género musical de raíces africanas, posiblemente de la región de Congo, desarrollado por los negros esclavos durante el siglo XVIII y XIX, en Cuba, Brasil, Argentina y Uruguay, principalmente. En cada una de estas regiones tuvo derivas históricas propias que lo llevaron a distinguirse, sin perder su marca de origen. En nuestro país el candombe se acunó y recreó en los sectores de Montevideo donde se concentraba la población de esclavos y libertos. [...] Tres tambores son los instrumentos principales del candombe uruguayo: piano, repique y chico. [...] La Comparsa es la agrupación típica que congrega a los personajes del candombe: La Mama Vieja, El Gramillero, El Escobero son seguidos por un nutrido grupo integrado por bailarines de ambos sexos. Completa la comparsa la cuerda de tambores, grupos de ejecutantes de tambores dispuestos en sucesivas líneas. (BRACCO [et al.], 2012, p. 32 , grifos nossos). 
A presença de elementos como o tambor de sopapo, a simbolizaçăo de figuras importantes para a cultura negra, como a Mama Vieja, que representa o culto à ancestralidade, e o ritmo versátil, que pode expressar desde sentimentos mais melancólicos, até a exaltaçấo e a alegria, sâo exemplos da força com que a cultura negra se manifesta em terras platinas. Fruto da herança africana trazida pelos escravizados, o Candombe é o ritmo que tem, em sua gênese, uma história marcada pela resistência, já que, pela persistência através da memória, e pelo desejo em náo perder os vínculos com a terra ancestral por meio da música, sua transmissăo e reatualizaçăo foi possível até a atualidade.

Uma das herdeiras e transmissoras dessa tradiçâo negra uruguaia, entâo, é Rosa Amelia Luna, nascida em 20 de junho de 1937, em Montevidéu, e falecida em 1993, no Canadá, vítima de um enfarto. Rosa nasceu no Conventillo Mediomundo², um cortiço reconhecidamente como um espaço afro-uruguaio.

\section{ROSA LUNA - A DEUSA DO CANDOMBE URUGUAIO}

Figura 1: Rosa sorri. [s.d.]. Página no Facebook dedicada à Rosa Luna.

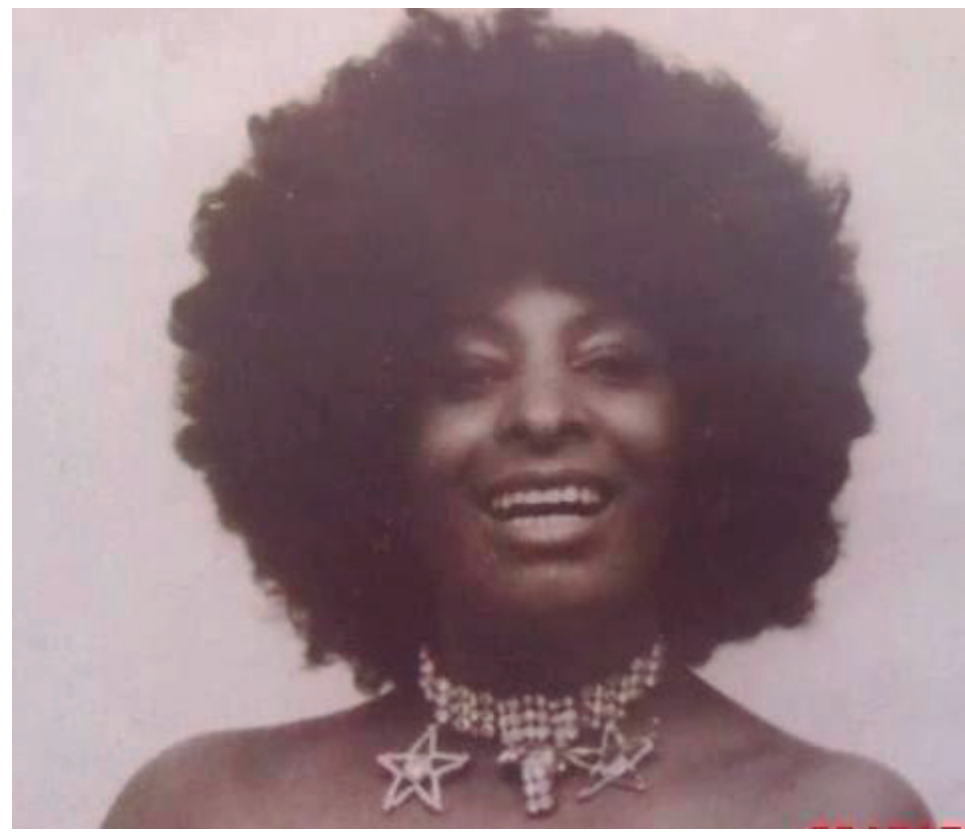

Disponível em: <https://pt-br.facebook.com/447731145355483/photos/a.447738598688071/145 5116681283586/?type=3\&theater> Acesso em: 16 jan. 2021.

2 Durante a ditadura militar, os moradores do Conventillo foram desalojados em 3 de dezembro de 1978, sob a alegaçáo de que a construçáo corria risco de desabamento. Em seguida, a construçáo foi demolida, e o terreno ficou vago por muitos anos. Hoje, no espaço foi construído um edifício de apartamentos. Em 2006, foi aprovada a Lei que institui o Día Nacional del Candombe, la Cultura Afrouruguaya y la Equidad Racial, que se comemora no dia 3 de dezembro, em homenagem ao Conventillo. Diante da açâo de despejo e demoliçáo, fica a dúvida: a construçáo realmente apresentava riscos ou o despejo foi uma açáo de "limpeza", isto é, de eliminaçáo da cultura negra e sua unidade de resistência no prédio? Disponível em: <https://www.lr21.com.uy/cultura/342734-medio-mundo-sur-conventillo-y-despuesun-libro-de-milita-alfaro?utm_source=redirects\&utm_medium=dominiolargo\&utm_campaign=301 Redirects> Acesso em: 28 jan. 2021. 
Apesar do sequestro de sua cultura e território, e da violência sofrida pela imposiçăo do trabalho escravo, os africanos, ao chegarem às Américas, resistiram ao branqueamento total de suas identidades pelo colonizador. É por isso que, traços culturais marcantes, como religiōes de origem africana, línguas, danças e saberes ancestrais permanecem vivos depois de tanto tempo, mesmo com a tentativa incessante dos brancos em marginalizar e apagar qualquer traço que permitisse aos escravizados sentir orgulho de suas origens e lutar, unidos, contra a dominaçăo.

Enquanto espaço de resistência e orgulho identitário, pode-se afirmar, com base em Abella (2007), que os conventillos - cortiços, săo o lócus coletivo de expressâo afro-uruguaia:

Los conventillos en El Río de la Plata (cuarterías en otras partes de América) son antiguas casas recicladas o modestas construcciones diseñadas expresamente para albergar a muchas familias que comparten servicios sanitarios y un patio central donde se lava y se tiende la ropa. Inmigrantes, obreros y gente del interior construyen allí una cultura "orillera" donde se comparten los eventos cotidianos como una familia extensa. Los amplios patios de estas residencias colectivas serán la cuna de formas musicales y literarias de gran belleza y originalidad. (ABELLA, 2007, p. 177).

Apesar de os cortiços serem construçôes inicialmente pensadas para abrigar os imigrantes, esse espaço passa a ser ocupado pela populaçấo negra à medida que os imigrantes europeus progridem economicamente. Diante do conglomerado de vozes, portas e vidas que se encontram nos espaços dos conventillos, destaca-se a coletividade que organiza aquelas vidas. Apesar de sujeitos únicos e independentes, é na coletividade, nas vivências e na constituiçâo de um corpo-voz coletivo que a expressăo afro-uruguaia se fortalece e permite que novas expressôes culturais ancestrais se atualizem e continuem a ecoar no processo de conexăo com a cultura africana. É justamente nos pátios desses cortiços que os afrodescendentes “[...] se templarán al fuego los tambores de candombe." (ABELLA, 2007, p. 178).

Figura 2: Conventillo Mediomundo, rua Cuareim 1080, bairro Sul. Casa de Rosa Luna nos primeiros anos de vida. [s.d.].

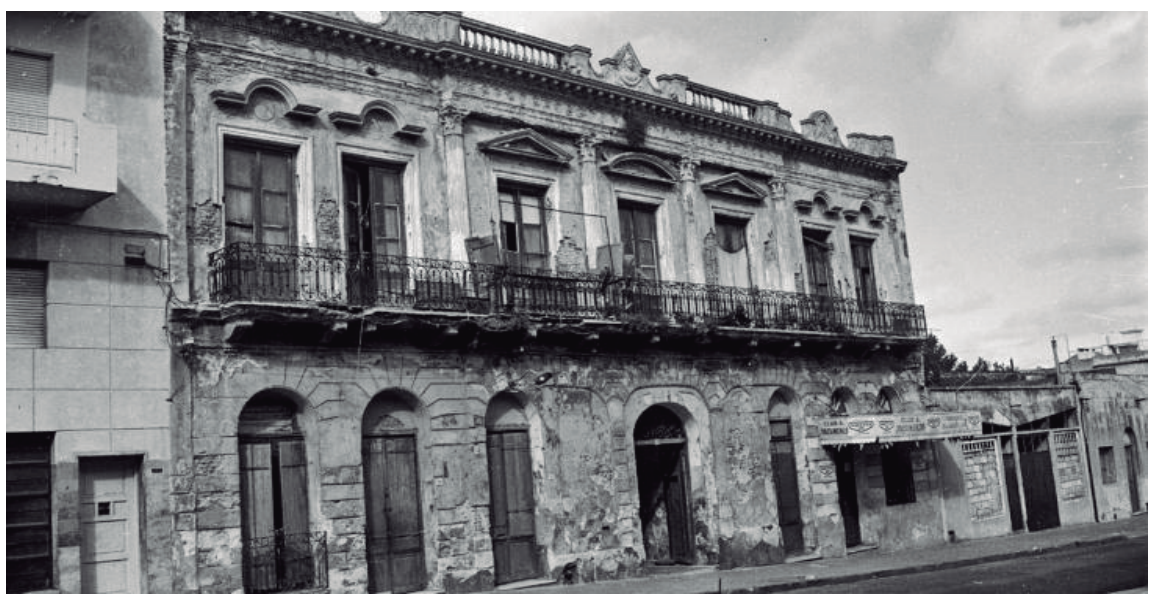

Site Montevideo Antiguo. Disponível em: <https://montevideoantiguo.net/index.php/ausentes/conventillomediomundo.html> Acesso em: 16 jan. 2021. 
Figura 3: Pátio interno do Conventillo. No local, aconteciam festas no ritmo do Candombe. [s.d.]. Site Montevideo Antiguo.

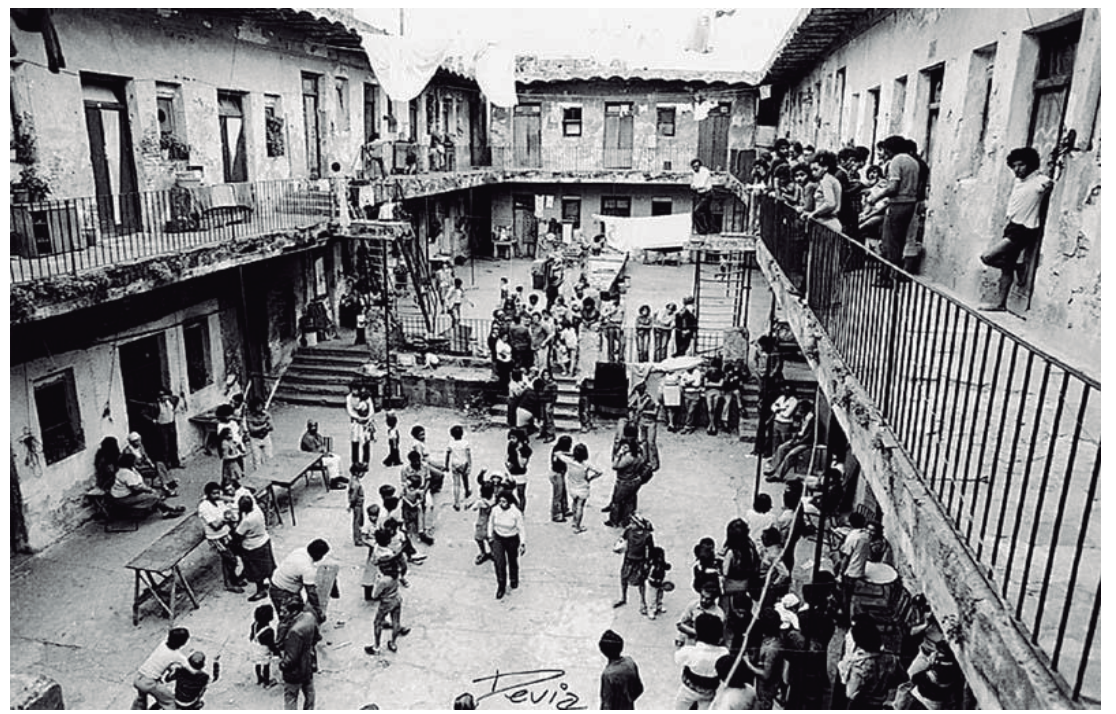

Disponível em: <https://montevideoantiguo.net/index.php/ausentes/conventillo-mediomundo. html> Acesso em: 16 jan. 2021.

Assim, em La diosa y la noche, observa-se o destaque ao Candombe enquanto característica genuinamente afro-uruguaia e como componente importante para a identidade e constituiçâo da protagonista Rosa Luna. Rosa Amelia Luna foi uma grande celebridade uruguaia e a mais famosa vedete do carnaval nacional. Sua primeira casa, o Conventillo Mediomundo, era conhecido por ser um centro da cultura afro-uruguaia e de culto ao Candombe. Tanto os espaços, quanto os fatos marcantes na vida da vedete sáo representados pelo escritor Jorge Chagas na narrativa que năo apenas ficcionaliza fatos biográficos da vida de Rosa à medida que reconta sua trajetória, como tenta reconstruir seu passado.

Figura 4: Rosa Luna no carnaval uruguaio. [s.d.]. Jornal La República.

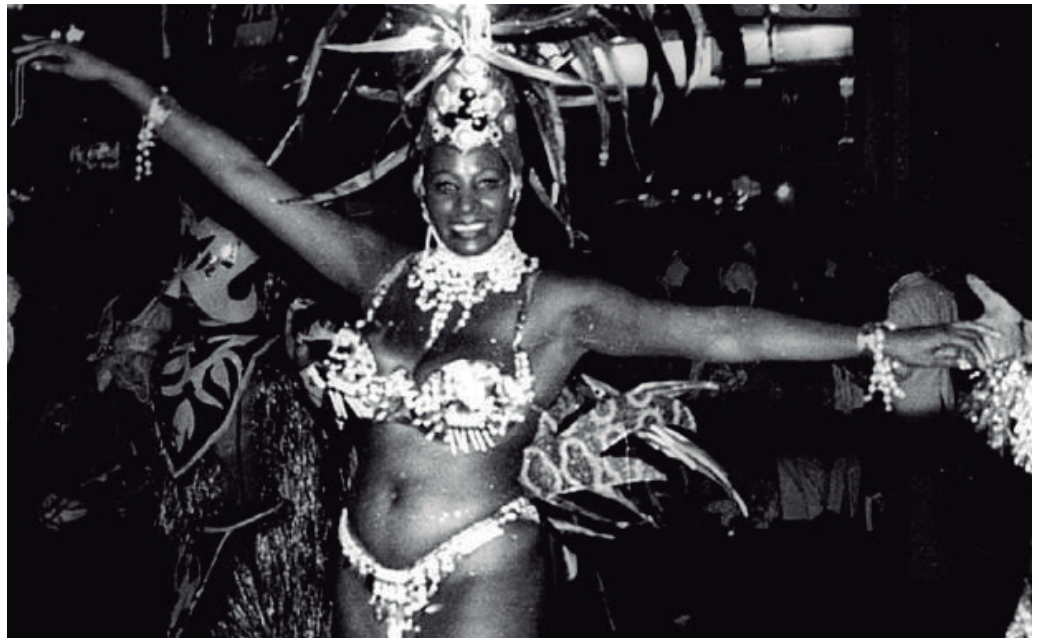

Disponível em: <https://www.republica.com.uy/presentaron-libro-de-rosa-luna/> Acesso em: 16 jan. 2021. 
Na primeira cena da obra, o escritor descreve o diálogo de dois homens que participaram do funeral de Rosa, dando a entender que foi enterrada ao som do Candombe:

¿La conocías bien? -quiso el joven.

Fuimos compañeros en Morenada, Farándula Negra, Serenata Africana y Raíces, a fines de los sesenta, esa fue una de las últimas veces que Santiago Luz hizo sonar su clarinete mágico. Sí... hicimos muchísimos tablados con Rosa.

¿Cómo era?

Una mujer sencilla, sin aspavientos.

¿Ah, sí? Eso es poco común en las vedettes de carnaval.

El veterano sonrió y acarició con suavidad la lonja de su tambor. Lo había bautizado El Ronco y era como un hermano. Con los años se convenció de que los sonidos que le sacaba eran una ofrenda que él hacia adelante como si quisiera ver algo estaba más allá. (CHAGAS, 2017, p. 9-10).

Assim, Chagas mescla a narrativa sobre Rosa com a de outras duas personagens que têm ligaçăo com a protagonista: o músico Frederico Brossman, um pianista que perdeu sua memória e tenta recobrar o seu passado, e Lídia, que está no Canadá, e troca cartas nas quais relembra as memórias do Uruguai com sua irmă e tenta descobrir quem é a mulher com quem tem sonhado. A presença desses dois outros personagens ajuda a recompor o passado de Rosa ao passo que segue um percurso de humanizaçáo e homenagem à vida da vedete. Ao seguir três linhas narrativas, Chagas desenleia a relaçấo entre os três personagens e chega ao ponto que os une: a relaçấo com Rosa Luna.

Durante toda a narrativa, Rosa se encontra num espaço intermediário entre mundo físico e espiritual onde passa sua vida a limpo para um anciăo que pode ser interpretado como Deus, que na narrativa é representado com características "gaúchas" ou platinas. Numa das primeiras cenas, Rosa acorda e lembra-se das últimas memórias que possuía:

Estaba bailando. Eso es lo primero que recordó. Estaba bailando sobre un escenario de la ciudad de Toronto, en Canadá. Lejos, muy lejos, de su hogar y de su hijo Rulito. Estaba bailando y los tambores sonaban cada vez más fuertes. Por un momento le faltó el aire. Sintió que sus piernas flaqueaban y tuvo que hacer un esfuerzo titánico para no perder el ritmo. (CHAGAS, 2017, p. 21).

Nesse momento, passa um filme em sua cabeça, de como fizera a viagem ao Canadá a contragosto, e de como sentia falta de casa, de seu filho. Relembra, também, de sua infância, de quando morava no Conventillo Mediomundo, e de quando ainda sonhava com a fama. Depois de todas essas memórias, Rosa acorda do sonho:

[...] tenía una extraña sensación que le invadía todo el cuerpo, como si se hubiera despertado de golpe sin haber dormido.

¿Dónde estoy? - se preguntó en voz baja.

Miró alrededor y quedó tan perpleja que por un largo instante no atinó a nada. Y al fin, se hizo otra vez a la misma pregunta. Pero ahora fue casi un grito.

¿¿Dónde estoy?!(CHAGAS, 2017, p. 26). 
Neste momento, Rosa se encontra num entrelugar, entre o céu e o inferno, entre o físico e o espiritual, um espaço repleto de grandes árvores, de flores muito perfumadas e brilhantes. Enquanto raciocinava se estava sonhando ou năo, é interrompida: ¿Qué tal, Rosita?"(CHAGAS, 2017, p. 42). Se tratava de um homem alto, magro e narigudo, com bigode, de língua bifurcada, portando um bastăo de cobra. Se tratava do diabo, ou o 'Risa Falsa', que contou à Rosa sobre sua morte, e que ali estava para lhe fazer uma proposta: "[...] No me gusta ser presumido, pero tengo el poder de cambiar eso. Si aceptas, te envío de vuelta."(CHAGAS, 2017, p. 45), ao que Rosa nega e sai correndo, pois para retornar à vida, deveria dar algo em troca ao diabo, e negar a Deus.

Depois de muito correr, ela se depara com uma escada e decide subir. A escada era interminável, e à medida que subia, mais comprida ficava. Exausta, entâo, Rosa decide fazer uma oraçăo; "[...] Querido Dios, no sé si oyes a esta negrita, pero igual me dirijo a vos, quiero pedirte que..." (CHAGAS, 2017, p. 72), mas mal terminou a oraçăo, e começou a ouvir uma música muito bonita, que a serenou e a fez subir a escada com calma. Ao fim da subida, encontrou um ambiente brilhante, e uma figura curiosa:

[...] era un anciano esmirriado de barba blanca y color de piel indefinido, que llevaba un sombrero de ala ancha. Vestía una camisa tan descosida como descolorida. Sus pantalones estaban surcados por un sinfín de costuras y remiendos. Calzaba unas zapatillas gastadas, con agujeros en las puntas. Estaba sentado en una pequeña silla, tomando mate. (CHAGAS, 2017, p. 73).

Quando perguntado sobre quem era, o anciăo responde de forma indefinida: "Yo soy quien soy." (CHAGAS, 2017, p. 74). A partir daí, os dois começam a conversar sobre a imagem 'padrăo' que Deus teria, sobre as tentativas de 'Risa Falsa' em corromper as pessoas, sobre virtudes e sobre pecados. $O$ anciấo, nesse momento, lembra Rosa Luna de que, apesar de seus erros, a maior das virtudes da vedete quando em vida foi a compaixăo. Depois de adentrarem nos assuntos de vida e morte, e os desígnios de Deus para com os seres humanos, Rosa pergunta ao anciăo sobre as duas pesadas portas de madeira que estavam às costas dele: “¿Podré entrar...?" (CHAGAS, 2017, p. 93), ao que o anciăo responde que, para passar pelas portas, seria necessário um teste. Ela deveria percorrer um caminho difícil e se despir perante o anciăo, isto é, mostrar o que havia em sua alma.

Rosa, entâo, começa a falar de sua infância e de como foi um tempo difícil. Sua mâe, Chunga, lavava roupa para fora e havia criado Rosa sozinha, uma vez que o companheiro a abandonara, recusando-se a reconhecer a paternidade de Rosa. A protagonista lembra, entăo, da última vez que viu o pai no leito de morte e de quando teve vontade de destratá-lo por ter sido um pai ausente. Rosa, entretanto, poupa o pai de tamanha tristeza, e demonstra compaixăo ao estabelecer, com ele, uma relaçăo de filha.

A vida da protagonista foi, também, marcada pela violência. Após a morte da mâe, Rosa Luna foi vítima do padrasto, que năo só era violento para com ela, como a obrigou a trabalhar desde muito nova:

Allí estaba ella, sentada en un banquito del patio, llorando desconsoladamente. Parecía estar margullada o algo así... También pude ver una figura luminosa, como un oso negro bamboleándose pesadamente, que se alejaba dando grandes trancos. A pesar de estar de espaldas, lo reconocí: era su padrastro. [...] De repente se dio 
vuelta violentamente, tenía los puños cerrados y me observó con unos ojos que desprendían fuego. (CHAGAS, 2017, p. 29).

Os episódios de sofrimento nas vivências da personagem se repetem quando, em outro momento, o Anciăo pede a Rosa que fale da senhora Hortensia Gómez de Linares. Se tratava da filha da família para a qual o padrasto de Rosa tinha forçado-a a trabalhar: "Y esa 'señorita Hortensia... era una agrandada, una mandona, insoportable, actuaba siempre como una princesa malcriada a la cual había que concederle todos los caprichos." (CHAGAS, 2017, p. 141). Apesar de ser mal tratada pela família e por Hortensia, Rosa age com compaixăo para com eles. Certo dia, quando ia até o jardim de inverno pegar um par de chinelos que havia esquecido, Rosa se depara com um encontro amoroso de Hortensia. A menina, que servia de exemplo para a família destacar as virtudes de uma branca, pura, quando em comparaçăo aos sujeitos negros, vistos como libidinosos, estava tendo relaçôes sexuais com o namorado. Rosa poderia, entâo, desmoralizar Hortensia perante a família e se vingar de tanta exploraçăo. Mas, mais uma vez demonstrando compaixăo, ela decide poupar a saúde do patrăo, que era muito frágil, e evita arruinar a honra da menina em um tempo em que a virgindade era motivo de orgulho e respeito.

Num terceiro episódio, Rosa se lembra de quando foi ao clube Mar de Fondo e se tornou bailarina. No teste para dançar no clube, a protagonista conheceu Solange Ramos, que tinha um grande ego, e que náo só se achava melhor do que as demais, como queria ensiná-las a dançar. Apesar de ser uma excelente dançarina de Candombe, Rosa humildemente finge ser uma iniciante para năo ofuscar a dança das outras competidoras. Muitas das concorrentes eram mâes solteiras e meninas humildes em busca de um sonho, mulheres que precisavam do emprego tanto quanto ou mais que Rosa, por isso ela decide ajudá-las.

Até mesmo quando foi impedida de entrar num baile organizado pela comunidade negra em Montevidéu, discriminada por sua própria gente, Rosa poupou a alta sociedade negra de insultos. Ela decidiu poupar os altos intelectuais negros dos fatos indignos que tentavam omitir, como o envolvimento com cabarés e gente de baixa condiçâo, porque, afinal de contas, eles estavam lutando e ajudando na conquista de direitos pela populaçăo afro-uruguaia.

Outro episódio de compaixăo na trajetória da personagem é narrado quando ela se lembra de seu primeiro casamento. Năo amava o primeiro marido, mas casou-se com ele para realizar o sonho dele em se casar com a "Deusa do Candombe". Pouco tempo depois, o marido percebeu seu erro, entăo se separaram e mantiveram uma saudável amizade.

Todavia, a única vez em que Rosa năo teve compaixăo foi quando matou um homem, em 1968, no Café Antequera, em Montevidéu, num ato de legítima defesa:

Hubo una vez en que no tuve compasión. Fue la peor noche de mi vida... [...] Yo... manché mis manos de sangre... actué sin pensar... fue algo instintivo. Ese hombre, Nicodemo, ni siquiera era mi enemigo. Sé que cometí un pecado terrible. La vida humana es sagrada y yo... yo no tenía ningún derecho a hacer lo que hice. La justicia me dejó libre, la gente me perdonó, pero yo nunca pude perdonar a mí misma... (CHAGAS, 2017, p. 197). 
Num ato de revolta, depois de liberada pela polícia, Rosa se irrita com Deus e promete, a partir daí, adorar a 'Risa Falsa', personagem que representa o diabo. No trajeto para casa, porém, um gesto de compaixăo para com Rosa modifica tudo:

[...] Subí a un ómnibus que estaba casi vacío y me senté en la parte trasera. Ahí estaba un muchacho y creo, por la forma en que me miraba, que me reconoció, aunque no dijo nada. Parecía muy tímido. En ese momento sentí frío y me di cuenta de que me había olvidado del abrigo en la comisaría. Me acurrequé en el asiento con los brazos alrededor del cuerpo y él, con gentileza, me dio su abrigo para que me cubriera. Yo le regalé una sonrisa por ese gesto, porque ese pequeño gesto tuvo un inmenso significado para mí: me recordó que había en el mundo personas capaces de buenas acciones, de ser generosas... eso me calmó y cuando volví a casa te recé... (CHAGAS, 2017, p. 199).

Depois de passar seu passado a limpo para o anciâo, Rosa Luna entra no céu dançando alegremente. No momento que atravessa o portal, uma luz a encobre, iluminando os passos da deusa do Candombe uruguaio. No final da história, entăo, é revelada a relaçăo entre os três personagens. O homem que havia ajudado Rosa no ônibus era Federico Brosman, um famoso pianista e professor de piano. Na ânsia por compor a música perfeita, o homem acaba fazendo amizade com "Risa Falsa" e se distancia da família, dos amigos e da religiăo. Ele havia perdido a memória e acorda no hospital. A influência da entidade maligna o fizera colocar a própria măe no asilo. Năo bastasse isso, se afasta da mulher grávida e fica indiferente quando o filho morre. Ao almejar a fama e a glória, Brosman decide escrever um musical. Quando recobra a memória, descobre que o musical estava pronto e era sobre a vida de Rosa Luna.

A conexăo com Lídia e a terceira linha da narrativa é revelada, por outro lado, por meio de cartas e da presença da memória infantil. Nas cartas que troca com a irmá, Lidia lembra o tempo todo da vida do Uruguai, das pessoas que faziam parte da sua vida, e da saudade que sente por estar no Canadá. Lidia relata, numa das cartas, um sonho em que encontrava alguém conhecido no Club Uruguay Toronto. Esse sonho antecipa a ida de Rosa ao Canadá para se apresentar, mas que Lidia sonha/prevê o encontro. A partir daí, a conexâo de Lídia com Rosa é revelada: "[falando com a irmâ] Nosotras, no tengo ninguna vergüanza en decirlo, fuimos afortunadas al tener unos padres que eran dueños del almacén que estaba frente a aquel conventillo que hoy es leyenda. [...] Entonzes comenzaron a llegar las primeras familias negras." (CHAGAS, 2017, p. 32, grifo nosso). Na carta, ela recorda de como brancos e negros conviviam pacificamente no cortiço, e de como, juntos, constituíam uma grande família.

As memórias envolvendo Rosa Luna vêm à tona após o anúncio sobre um show que aconteceria no Clube Urugay Toronto: "Rosa Amelia, como la llamaba mamá, vivía en una de las habitaciones del piso de arriba del Mediomundo. Era una de las hijas de doña Ceferina, a la que llamaban la 'Chunga". (CHAGAS, 2017, p. 174). Quando criança, Lidia e Rosa conviveram no cortiço:

De todas formas compartimos con ella y sus hermanos muchos juegos en la calle o en el patio del conventillo. [...] una vez mamá invitó Rosa Amelia a ir con nosotras al biógrafo Atenas que estaba sobre la calle Maldonado y Tacuarembó. Supongo que lo hizo para darle, aunque fuese por un par de horas, unos momentos de alegría. Fuimos 
a ver una de aquellas películas de alfombras mágicas, espadachines, doncellas en peligro que gritaban histéricas, héroes galantes que corrían presurosos a su rescate y el beso final antes del 'The End'. Rosa Amelia pareció divertirse a lo grande, pero cuando retornábamos a casa estuvo muy silenciosa, como distraída. En el momento que llegamos y ella estaba por entrar al Mediomundo le hizo a mamá una pregunta que en aquel momento - creo - ni vos ni yo comprendimos totalmente: 'Por qué no viene un príncipe azul a rescatarme a mí?'(CHAGAS, 2017, p. 175).

As memórias de Lidia nas cartas ajudam o leitor a descobrir mais sobre o passado da protagonista, de como levava uma vida difícil e escassa de recursos no Conventillo Mediomundo. Em um sonho, Lidia relembra de como também encontrou Risa Falsa quando era criança nas redondezas do Conventillo. Ele a dizia para se afastar daquele lugar de fracassados, de negros que năo valiam nada, que ela deveria sair dali e ter orgulho de sua pele branca, ao que Lidia rejeita gritando.

Diante de tantos trechos, passagens, memórias, cartas e depoimentos, uma característica de Rosa se sobressai: ela era uma verdadeira deusa do carnaval uruguaio. Esse título năo se deve unicamente pela beleza da dança da protagonista, que se destacava no carnaval e no Candombe, mas também pelo seu caráter e personalidade. Rosa era descrita como humana, correta, brava, de gênio forte e alma doce. Pode-se afirmar que ela era muito querida pelos uruguaios, se firmando como uma espécie de heroína nacional, que os orgulhava e os embalava nos tambores do ritmo afro-uruguaio Candombe.

Por outro lado, a representaçăo literária atenta à cultura negra e suas características, assim como a narraçâo que, muito mais do que "falar por", permite que Rosa fale em primeira pessoa, săo características da prática de uma literatura com bases afro-centradas pelo escritor uruguaio Jorge Chagas. À medida que revisita o passado de Rosa, e ficcionaliza sua trajetória contando fatos de sua vida, o escritor amplia imagem da protagonista para além de estereótipos, no sentido de mostrar que, muito mais do que uma estrela do carnaval, Rosa Luna era, sobretudo, uma mulher, mâe, negra, forte, empoderada e que fazia sua voz ser ouvida.

\section{AFROCENTRICIDADE E LITERATURA}

Além de Arte, a Literatura é, sobretudo, um instrumento de voz. Apesar disso, dentre a multiplicidade de vozes existentes, por muito tempo, a Literatura escutou e registrou "vozes que importavam mais", de determinado nível social, de cultura específica e a partir de uma visăo parcial. Quando na 3 porque:

[...] Somente de um lugar centrado na experiência própria dos povos africanos é possível, no contexto social do supremacismo branco, perceber a brancura como etnicidade específica, pois a sociedade a apresenta como norma universal, pano de fundo, identidade subjacente e universal que náo precisa se articular. (NASCIMENTO, 2009, p. 190, grifos da autora).

Pensando mais especificamente a partir da América Latina, o movimento de valorizaçăo das raízes negras constitui, sobretudo, um movimento literário, o Afro-realismo, conceito elaborado por Quince Duncan. A partir de um movimento que rompe com a 
visăo de que na América hispânica existe apenas uma cultura étnica - a branca, europeia e espanhola, Duncan (2005), identifica a expressão de uma literatura de bases negras em diversos países latinos. Para esse movimento, ele escolhe o nome "Afrorealismo", cuja existência

[...] se justifica porque esta corriente literaria no utiliza los referentes tradicionales de la literatura del "main stream", como lo hacen los escritores del "boom". No evoca al mito griego, ni al folklorismo. No es literatura negrista ni sigue la corriente de negritude. No es realismo mágico. Es una nueva expresión, que realiza una subversión africanizante del idioma, recurriendo a referentes míticos inéditos o hasta ahora marginales, tales como el Muntu, el Samanfo, el Ebeyiye, la reivindicación de las deidades como Yemayá, y a la incorporación de elementos del inglés criollo costeño. (DUNCAN, 2005, [s.p.], grifo nosso).

Assim, Duncan (2005) propôe seis perspectivas para pensar o romance com características Afro-realistas. A primeira delas é 1) El esfuerzo por restituir la voz afro americana por medio del uso de una terminología afro céntrica. Apesar de se tratar de uma descentralizaçáo linguística, identificamos a presença dessa primeira característica afro-realista na obra La diosa y la noche pela expressâo de uma voz negra cantada, por meio do Candombe, e que serve como pano de fundo durante toda a narrativa pelo ritmo e o tom orgulhoso com que a raiz africana presente nessa herança cultural é representada. A presença de uma voz melodiosa negra no romance só é possível pelo som do tambor de sopapo, instrumento trazido na diáspora africana pelos escravizados e que, apesar do tempo, resiste e persiste na tarefa de ecoar as vozes do outro lado do oceano até a América do Sul.

A segunda característica é 2) La reivindicación de la memoria simbólica africana. Nesse tópico, Duncan (2005) discute o direito de o sujeito negro pertencer, redescobrir e restabelecer laços com as raízes ancestrais. Violadas com a branquitude e europeizaçâo, as culturas africanas, com frequência, eram vistas como inferiores, marginais e exclusivas dos níveis sociais mais baixos. Acreditamos que a presença deste elemento no romance se dá pela escolha temática feita pelo escritor Jorge Chagas, já que quando decide representar a vida de uma mulher negra, de origens humildes e que se torna símbolo nacional da cultura negra pelo carnaval, o escritor está exercendo o direito de reverter o apagamento histórico, de colocar no centro as narrativas e as vozes que, historicamente, ficaram à margem.

O terceiro tópico é 3) La reestructuración informada de la memoria histórica de la diáspora africana. Representar o passado e a importância de uma mulher negra uruguaia por meio da literatura é náo permitir que a memória acerca de Rosa se apague. Ao colocá-la no lugar que lhe é devido, sob os holofotes, aplausos e ao som do Candombe, Chagas (2017) reverte os preconceitos e racismos associados à cultura afro-uruguaia e busca reafirmar a presença negra no País, reconstruindo, assim, os laços da diáspora africana.

O quarto ponto diz respeito à 4) La reafirmación del concepto de comunidad ancestral. $\mathrm{O}$ aspecto comunitário, de formaçăo de um corpo coletivo, negro e uruguaio na obra pode ser associado à casa primeira de Rosa e o espaço que, simbolicamente, abrigava e protegia os candomberos - o Conventillo Mediomundo. A construçâo possui, desde sua gênese, o caráter coletivo - tratando-se de um cortiço, as pessoas que lá 
viviam compartilhavam experiências, culturas e a condiçăo econômica. O Conventillo constituía, de certa, forma, uma espécie de palenque ${ }^{3} u r b a n o$, onde os palenqueros - quilombolas, formavam um corpo de resistência, uma unidade identitária afro-uruguaia dentro de Montevidéu, fato que os tornava năo apenas uma comunidade, como também os representantes de uma importante herança cultural nacional.

A quinta perspectiva propóe pensar 5) La adopción de una perspectiva intra céntrica, isto é, a narraçăo fala a partir da comunidade, com uma voz própria, longe de estereótipos e visôes exóticas; enxerga a cultura e a comunidade como ela é. Um exemplo do olhar e voz afro-realistas na obra La diosa y la noche é a importância da religiosidade para a narrativa e o modo particular como ela é representada. Dois personagens materializam essa visăo afro-cristă: Risa Falsa, que pode ser entendido como uma visăo cosmogênica do diabo, e o anciăo afro-gaúcho, uma possível versăo de Deus ou Sáo Pedro. A apropriaçăo de elementos do cristianismo, e sua representaçấo a partir de um olhar afro-uruguaio, evidencia o compromisso com a cultura local, assim como o respeito à proposta ética da narrativa.

A sexta e última característica do Afro-realismo, 6) La búsqueda y proclamación de la identidad afro, é um elemento presente durante toda a obra La diosa y la noche, seja no modo como retrata os elementos que somam para a representaçâo da cultura negra, seja na escolha da temática que decide representar - a vedete Rosa Luna. Além de homenagear a populaçáo afro-uruguaia, entendemos que Chagas (2017) realiza um verdadeiro trabalho de restituiçăo da humanidade da personagem.

Tal açăo acontece em contraposiçăo ao fato de que, conforme Fanon (1968), a colonizaçăo expropriou a humanidade do sujeito negro, caracterizando-o sempre como inferior, animalizado, subalterno, selvagem e sexual; no "[...] contexto colonial, verifica-se que o que retalha o mundo é, antes de mais nada, o fato de pertencer ou nâo a tal espécie, a tal raça." (FANON, 1968, p. 29). Ficar condicionado à branquitude como categoria humana é uma forma de violência promovida principalmente pela instância linguística, que se encarrega de atribuir adjetivos racistas e formar imaginários colonizados.

Precisamente, é pela linguagem escrita que Jorge Chagas reverte este processo histórico e devolve a humanidade de Rosa Luna quando: a) retrata-a náo como mulher-objeto, sexual e exclusiva do carnaval, mas como cidadá comum, com defeitos e qualidades; b) quando traz à tona seu passado de pobreza e dificuldades, e desmistifica o glamour e a fama como únicas características da personagem; c) no momento em que esmiúça as faltas de Rosa durante a vida, fazendo-a lembrar de que, apesar dos erros, ela sempre foi uma pessoa boa, mesmo quando mata em legítima defesa; d) quando decide representar a morte da protagonista de forma alegre, em consonância à áurea que a envolvia - Rosa entra no céu dançando Candombe, demonstrando que, embora sua vida física tenha cessado, sua memória continua viva e reverberando.

Nessa perspectiva, entendemos que Jorge Chagas desempenha uma escrita de bases sociais e atentas à cultura negra. Sua literatura é, também, representativa, sobretudo,

3 A traduçăo de Palenque para o português brasileiro é Quilombo. Entretanto, no espanhol platino, Quilombo significa confusăo. (Informaçôes coletadas junto à professora e tradutora Dra. Líliam Ramos da Silva). 
pela voz que faz ouvir: sendo homem negro, o escritor representa uma parte da cultura uruguaia que, por muito tempo, foi esquecida ou deixada de lado, mas que hoje deve ser ouvida e redescoberta de modo a receber o devido reconhecimento perante a história nacional.

Figura 5: Jorge Nelson Chagas. Nascido em 1957, escritor, jornalista e historiador uruguaio.

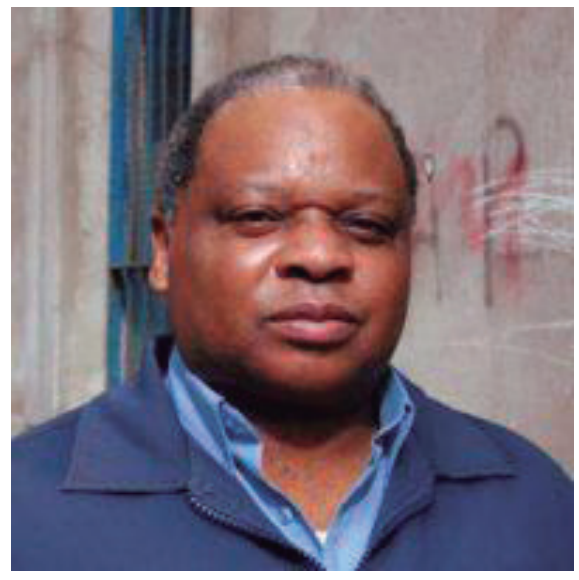

Disponível em: <https://www.findesiglo.com.uy/portfolio-item/jorge-chagas/> Acesso em: 22 jan. 2021.

\section{CONSIDERAÇÕES FINAIS}

À vista disso, este trabalho teve como objetivo investigar a obra La diosa y la noche, do escritor Jorge Chagas enquanto expressâo de uma literatura afro-centrada e que privilegia a humanizaçâo do sujeito negro, no caso, a vedete Rosa Luna, da mesma forma que promove a revisăo histórica da negritude uruguaia.

Inicialmente, realizamos o percurso histórico da presença negra no Uruguai, e de sua invisibilidade, característica herdada da colonizaçáo e que visava à negaçăo náo apenas das práticas culturais dos povos negros, como também a negaçăo da própria existência do sujeito negro como ser humano. Como forma de violência, o colonizador europeu náo só explorou fisicamente a força de trabalho dos escravizados, como também, a fim de torná-lo um subalterno e inferior à branquitude, criou processos que legitimassem a condiçấo de escravidăo. Na história do Uruguai, tal perspectiva pode ser percebida na "liberdade condicional" do escravizado, quando devia cumprir serviço militar obrigatório e lutar na guerra por sua liberdade, mesmo já a tendo garantida pela publicaçăo de várias leis que determinavam tal açăo, mas que năo eram cumpridas a fim de continuar a dominaçâo e os benefícios dos senhores.

Outra forma de criaçăo do status de escravizado aconteceu por meio das ciências, que criaram diferenças entre negros e brancos tendo este último como critério de comparaçăo, e assim justificavam a dominaçâo branca europeia sobre as demais culturas, a negra e a indígena, principalmente. Parte dos débitos adquiridos com a corroboraçáo da hierarquizaçâo racial pelas ciências humanas e exatas começa a ser subtraído apenas na contemporaneidade, quando vozes que sempre falaram, mas nem sempre foram escutadas, começam a receber a devida atençăo, respeito e espaço público para debate. 
Se no passado a literatura foi um meio de divulgaçăo do racismo, agora ela se torna exatamente o oposto, firmando-se como instrumento de empoderamento e denúncia.

Por conseguinte, Jorge Chagas, a partir de uma posiçâo atenta à realidade social, e que reescreve a memória uruguaia, representa a história de Rosa Luna, associando a escrita ao orgulho e valorizaçáo da cultura negra. Identificamos valores presentes na escrita da narrativa que evidenciam o paradigma afrocêntrico, que representa uma mudança no sentido de posicionamento e culturas de referência, assim como de modos de pensar, tendo como característica principal a crítica ao branqueamento da populaçâo negra, que "[...] deviam converter-se aos modos europeus para atingirem ao status plenos de seres humanos." (MAZAMA, 2009, p. 113).

A desconstruçăo do branqueamento imposto à cultura negra e a afirmaçáo de sua humanidade, envolve a revisâo histórica, a narraçăo de novas histórias e personagens, assim como a descriçăo de espaços significativos para essas culturas. Como exemplos de estratégias de resistência e afro-centrismo desempenhadas por Chagas através da literatura afro-realista, destacamos: a) a representaçăo de uma voz melodiosa negra para a narrativa, dando destaque à expressâo da cultura negra por meio do Candombe - ritmo e símbolo da herança ancestral; b) quando realiza o trabalho histórico de resgate da memória negra ao retratar as vivências de Rosa Luna; c) a reconexâo a cultura afro-uruguaia à cultura da diáspora africana; d) a representaçăo, por meio da literatura, a formaçăo de uma comunidade simbólica protegida pelos muros do Conventillo Mediomundo. A apropriaçáo do espaço pela relaçăo da populaçăo negra com o espaço é a expressăo de unidade e orgulho; e) da apropriaçăo da religiosidade cristă e sua representaçăo a partir de visóes firmadas na cultura local; f) na escolha da protagonista e a representaçăo de seu percurso, desde suas origens até a morte, trajetória repleta de conflitos, mas aos quais se sobressai com força e enfrentamento às injustiças.

Assim, entendemos que, por meio da literatura, Chagas resgata a humanidade de Rosa por meio da memória e a representaçâo da protagonista de modo ético, atento, e despido de estereótipos, praticando, portanto, uma literatura engajada e decolonial à medida que faz resistência e enfrentamento ao apagamento e violência empregados pela persistência da colonizaçâo nas relaçôes sociais até a atualidade. 


\section{REFERÊNCIAS}

ABELLA, Gonzalo. Historia diferente del Uruguay.4 ed. Montevideo: BETUMSAM Ediciones, 2007.

BRACCO, Roberto. [et al.]. Esclavitud y afro-descendientes en Uruguay: Una mirada desde la antropología. Facultad de Humanidades y Ciencias de la Educación, Universidad de la República. UDELAR: Montevidéu, 2012.

CABELLA, Wanda; NATHAN, Mathías; TENENBAUM, Mariana. La población afro-uruguaya en el Censo 2011. In: Atlas sociodemográfico y de la desigualdad del Uruguay. Disponível em: <http://www.ine.gub.uy/c/document_library/get_file?uuid=1726c03f-aecd-4c78-b9be-f2c27dafba1d\&groupId=10181> Acesso em: 25 abr. 2019.

CHAGAS, Jorge. La diosa y la noche. La novela de Rosa Luna.1 ed. Montevideo: Editorial Fin de Siglo, 2017.

CHAGAS, Karla; STALLA, Natalia. Recuperando la memoria: afrodescendientes em La frontera urugayo-brasileña a mediados del siglo XX. Mastergraf: Montevidéu, 2008.

DUNCAN, Quince. El Afrorealismo - Una dimensión nueva de la literatura latinoamericana. Istmo - Revista virtual de estudios literarios y culturales centroamericanos. n. 10 ene. - jun. 2005. Disponível em: <http://istmo.denison.edu/n10/articulos/afrorealismo. html> Acesso em: 25 jan. 2021.

FANON, Frantz. Os Condenados da Terra. Traduçâo de José Laurênio de Melo. Rio de Janeiro: Civilizaçăo Brasileira, 1968.

FINCH, Charles S.; NASCIMENTO, Elisa Larkin. Abordagem afrocentrada, história e evoluçāo. In: NASCIMENTO, Elisa Larkin (org.). Afrocentricidade: uma abordagem epistemológica inovadora. Săo Paulo: Selo Negro, 2009. Série Sankofa: matrizes africanas de cultura brasileira. pp. 37-70.

MAZAMA, Ama. A Afrocentricidade como um novo paradigma. In: NASCIMENTO, Elisa Larkin (org.). Afrocentricidade: uma abordagem epistemológica inovadora. Săo Paulo: Selo Negro, 2009. Série Sankofa: matrizes africanas de cultura brasileira. pp. 111-128.

NASCIMENTO, Elisa Larkin. In: (org.). Afrocentricidade: uma abordagem epistemológica inovadora. Sâo Paulo: Selo Negro, 2009. Série Sankofa: matrizes africanas de cultura brasileira. pp. 181-196. 